\title{
Małgorzata Karwatowska, Leszek Tymiakin Światy uczniowskie. Język - media - komunikacja Wydawnictwo Uniwersytetu Marii Curie-Skłodowskiej, Lublin 2014, ss. 422
}

Recenzowana książka składa się z tekstów już wcześniej opublikowanych. Nie jest jednak ich prostym przedrukiem. Jak zasadnie piszą o tym sami autorzy: „Opracowanie niniejsze zawiera prace pisane w ciągu kilku lat. Wprawdzie już wcześniej ukazały się one drukiem (o czym informujemy w Nocie wydawniczej), ale - w zasadzie - wszystkie zostały bądź rozszerzone, bądź przebadane, bądź uzupełnione" (s. 11).

Sami autorzy tak uzasadniają powtórne ich wydanie w jednej książce: „Wiele z nich [powtórnie tutaj wydanych prac - B.W] opublikowano w niskonakładowych wydawnictwach, trudno dziś dostępnych. Tymczasem te rozproszone teksty układają się $\mathrm{w}$ pewną całość, $\mathrm{w}$ niewielkim chociaż stopniu (taką przynajmniej mamy nadzieję) przybliżającą specyfikę przestrzeni, w której funkcjonuje współczesny uczeń" (s. 11).

Trudno w tym miejscu nie przywołać refleksji wybitnej uczonej, Elżbiety Smułkowej, na temat zbierania w jednej książce rozproszonej po różnych czasopismach i tomach zbiorowych twórczości naukowej (Smułkowa sformułowała tę refleksję w oczekującym na druk tomie Mowa mieszkańców pogranicza białorusko-polsko-litewskiego i inne szkice): „Wiem z doświadczenia, że dopiero zebranie artykułów drukowanych w różnych czasopismach $\mathrm{w}$ jednej książce zapewnia im odpowiedni obieg naukowy. W przeciwnym wypadku na ogół idą w zapomnienie i często następne pokolenia badaczy nie wiedzą lub nie chcą wiedzieć o ich istnieniu" (s. 5 tekstu Wspomnienie o przyjacielu).

Sąd jest niewątpliwie słuszny, choć akurat w wypadku rozproszonych po różnych czasopismach i książkach zbiorowych prac Małgorzaty Karwatowskiej i Leszka Tymiakina w żadnym wypadku nie wchodzi w grę 
ich zapomnienie. Niemniej jednak zebranie takich prac $\mathrm{w}$ jednej książce wydatnie ułatwia $\mathrm{z}$ nimi kontakt i potęguje ich oddziaływanie na środowisko naukowe i oświatowe. A wspomnianej wyżej zabiegi redakcyjne (w postaci rozszerzania, uzupełniania i „przebudowywania”) spowodowały, że powstała książka zwarta, spójna, która wcale nie sprawia wrażenia złożonej z powtórnie wydanych artykułów.

Dla porządku myślowego warto dodać, że na 27 opublikowanych w książce artykułów 10 jest autorstwa Małgorzaty Karwatowskiej, 9 - autorstwa Leszka Tymiakina, a 8 powstało we współautorstwie obojga lubelskich dydaktyków języka.

Małgorzata Karwatowska i Leszek Tymiakin są bowiem językoznawcami - dydaktykami języka polskiego. $\mathrm{W}$ ich dorobku naukowym prace stricte lingwistyczne współistnieją z takimi, które relacjonują wyniki badań w zakresie dydaktyki języka polskiego. Ścisłej granicy między tymi dwoma obszarami niepodobna zresztą wykreślić. Rozległe pogranicze miedzy nimi wypełniają studia nad językiem uczniów szkół podstawowych i średnich. Z jednej strony są to niewątpliwie prace językoznawcze, tj. opisy odmiany bio- i socjolektalnej współczesnej polszczyzny (o takiej kwalifikacji decyduje wiek użytkowników i ich status uczniowski), z drugiej zaś - przy opisie polszczyzny uczniów nie sposób pominąć aspektu dydaktycznego.

Zebrane w książce prace układają się w trzy księgi tematyczno-problemowe. Pierwszy wypełniają studia nad rozumieniem ważnych pojęć (w dużej mierze aksjologicznych) i leksemów w języku nastolatków uczniów gimnazjalnych i licealnych. Znajdujemy tu studia na temat światła, lęku, nienawiści, kłamstwa, seksu, tolerancji religijnej i Żyda/żyda. Sami autorzy piszą we Wprowadzeniu: „Bohaterami tej książki są uczniowie, głównie gimnazjów i liceów, ale też szkół podstawowych, techników, a nawet wyższych uczelni. Staramy się w niej pokazać wiedzę oraz sposoby posługiwania się przez młodych ludzi wybranymi pojęciami, leksemami i gatunkami mowy. [...]. Szczególnie interesuje nas sprawność przedstawicieli młodzieży w porozumiewaniu się [...]. Niezwykle ważna w takim kontekście okazuje się kwestia uczniowskiej kompetencji aksjolingwistycznej, której znaczenie nieustannie podkreślamy" (s. 9).

I jeszcze jedno przytoczenie $\mathrm{z}$ recenzowanej książki: „Tytułowe «światy uczniowskie» mają w założeniu autorskim pokazać funkcjonowanie ucznia $w$ trzech obszarach, czyli w języku, mediach i komunikacji" (s. 10). 
Na obszar językowy składają się, jak już stwierdziliśmy, studia nad ważnymi pojęciami i leksemami w polszczyźnie uczniów. Język, jak słusznie przypominają autorzy, służy do konceptualizacji i werbalizowania wiedzy w świecie oraz do wyrażania sądów i emocji, kształtując równocześnie świadomość swoich użytkowników. Media (tutaj głównie czasopisma adresowane do młodzieży, lecz także gazetki szkolne, telewizja, a za pośrednictwem mediów cała sfera kultury popularnej) to z kolei najbardziej dziś istotny czynnik wpływający na młodzież. Współczesne media nie tylko stwarzają praktycznie nieograniczone możliwości komunikacyjne, lecz także decydują o dzisiejszej organizacji społecznej i kształcie kultury. I wreszcie komunikacja, pojęcie zakresowo najszersze, obejmuje prace na temat uczniowskiej kompetencji komunikacyjnej (między innymi należy tu „tradycyjna” umiejętność analizy i interpretacji tekstu literackiego, a także nowa potrzebna umiejętność (zadanie edukacyjne) prowadzenie negocjacji).

Książkę dopełnia kilka studiów zgrupowanych w dodatkowym dziale Przydatne uzupełnienie. Ze światów nauczyciela, traktujących głównie o relacjach między szkołą a modelem nowoczesnego kształcenia językowego.

O wartości recenzowanej książki stanowią, w moim przekonaniu, głównie następujące elementy:

1) Solidny warsztat lingwistyczny autorów, skutkujący precyzją i wnikliwością opisów i analiz zgromadzonego i poddanego interpretacji materiału językowego.

2) Cechująca autorów chwalebna ostrożność w wyciąganiu wniosków i formułowaniu tez.

3) Wieloletnie doświadczenie dydaktyczne obojga autorów, owocujące przekonującymi, uzasadnionymi diagnozami i zaleceniami pedagogicznymi.

4) Doniosłość społeczna książki, wynikająca z tego, że traktuje ona o sprawności językowej i komunikacyjnej młodzieży, która jest, jakkolwiek by to górnolotnie zabrzmiało, przyszłością narodu.

Jestem przekonany, że wartościowa, potrzebna i pożyteczna książka Małgorzaty Karwatowskiej i Leszka Tymiakina znajdzie licznych i uważnych czytelników, głównie z kręgu nauczycieli i studentów zainteresowanych współczesną polską szkołą.

Bogdan Walczak

Uniwersytet im. Adama Mickiewicza

Państwowa Wyższa Szkoła Zawodowa im. Jakuba z Paradyża w Gorzowie Wielkopolskim 